\title{
Molecular Marker to Identify Two Stingless Bee Species: Tetragonisca angustula and Tetragonisca fiebrigi (Hymenoptera, Meliponinae)
}

by

\begin{abstract}
Ana Lúcia Paz Barateiro Stuchi ${ }^{1}$, Vagner de Alencar Arnaut de Toledo ${ }^{2}$, Denise Alves Lopes ${ }^{1}$, Liriana Belizário Cantagalli ${ }^{1}$

\& Maria Claudia Colla Ruvolo-Takasusuki ${ }^{{ }^{*}}$
\end{abstract}

\section{ABSTRACT}

Tetragonisca angustula and T.fiebrigiesterases were biochemically characterized by their inhibition pattern and thermostability. Workers of both species were collected from nests at the State University of Maringá. In T. fiebrigi three esterases were observed: EST-1 ( $\beta$-esterase, cholinesterase I), EST-2 $(\alpha$-esterase, cholinesterase II) and EST- 4 ( $\alpha \beta$-esterase, carboxylesterase). In T. angustula two esterases were detected: EST-3 ( $\beta$-esterase, acetylesterase) e EST-4( $\alpha \beta$-esterase, carboxylesterase). T. angustula EST-3 showed the highest thermostability, and it was not observed above $54^{\circ} \mathrm{C}$, while in T. fiebrigi EST1 and EST-2 were not detected above $52^{\circ} \mathrm{C}$. Through this characterization, it was observed that EST-4 of T. angustula and T. fiebrigi showed identical biochemical characteristics, and probably those esterases are encoded by the same gene in the two species. Together, the biochemical characterization and molecular markers show that the two species are differentiated and secondary contact between the populations can still be occurring.

Key words: stingless bees, isoenzymes, inhibition, thermostability, taxonomy

\section{INTRODUTION}

The stingless bees evolved from a group of wasps which at some point in evolution no longer transmitted to its descendants the genetic characteristics

Universidade Estadual de Maringá, Departamento de Biologia Celular e Genética, Av. Colombo, 5790, Maringá - Paraná - CEP 87.020-900, (44) 3261-4678.

${ }^{2}$ Universidade Estadual de Maringá, Departamento de Zootecnia, Av. Colombo, 5790, Maringá Paraná - CEP 87.020-900.

*Corresponding author: mccrtakasusuki@uem.br 
responsible for the sting formation (Alonso 1998). The explanation for the sting loss in this group of bees is probably related to the fact that their colony is not exposed when the bees swarm, and they usually nest in concealed and well protected places (Alonso \& Paim 2001).

The stingless bees are among the most common pollinators of tropical environments, and in certain regions they are the dominant bee species, visiting various cultures (Macías-Macías et al. 2009). These insects are a diverse group, in which includes over 400 species which shows high variability in physiology, morphology and size, ranging from $0.2 \mathrm{~mm}$ in the genus Trigonisca to over $20 \mathrm{~mm}$ in some Melipona species (Michener 2000; Moure et al. 2007).

The meliponines are though to have originated in the Gondwana western continent; this hypothesis is based on the fossil findings and by biogeography (Camargo \& Menezes-Pedro 1992). They dwell mostly in regions of tropical and temperate subtropical weather of the world (Nogueira-Neto 1997).

According to Moure (1961), there are two tribes in the Meliponinae subfamily: Meliponini and Trigonini. The Meliponini are characterized for not building real cells, therefore, queens, workers and males born and develop to adulthood in cells of the same size. The Trigonini consists of a highly diversified group, with dozens of genera and often build real cells, bigger than the other, where queens-to-be emerge (Nogueira-Neto 1997).

According to Castanheira \& Contel (2005), in Tetragonisca angustula (Trigonini), there are two known subspecies, which are differentiated through the coloring of the mesepisterna. T. angustula angustula presents a black mesepisterna, while T. angustula fiebrigi presents a yellow one. However, according to Camargo \& Pedro (2007), they were considered as two taxonomically distinct species, T. angustula and T. fiebrigi.

Considering that there is still disagreement regarding the classification of these bees in species or subspecies, the development of new studies to detect the occurrence of markers which enable an accurate classification is essential.

The geographical distribution for T. angustula fiebrigi was firstly described by Schwarz (1938) and Nogueira-Neto (1970). This subspecies is present in Brazil in Mato Grosso state, in the Paraná river basin and also in Paraguay and Argentina. In 2005, Castanheira \& Contel (2005) related the occurrence of T. angustula fiebrigi in North-western Paraná, Londrina and Maringá counties. This subspecies was also collected in Altônia county, Paraná state (Ruiz 2006; Alves 2006). 
The subspecies T. angustula angustula is distributed in most states throughout Brazil (Iwama \& Melhem, 1979; Camargo \& Posey, 1990), as well as in Panama (Roubik 1983), Venezuela (Vit et al. 1994) and Costa Rica (Veen \& Sommeijer 2000a, b).

Regarding the population genetics studies and the differentiation between these two species, Oliveira et al. (2004), by using the molecular marker RAPD, identified a marker for the Tetragonisca subspecies, the primer OPL-11. Later, Baitala et al. (2006) showed that with the use of RAPD markers, it is only possible to separate populations of Tetragonisca, not being able to detect a marker for subspecies, even using the primer mentioned above.

Among the molecular markers, the esterase isoenzymes which present high multifunctional hydrolytic activity and catalyze the hydrolysis of a large number of esters can be highlighted (Walker \& Mackeness 1983). Based on the sensibility to the synthetic substrate which those enzymes hydrolyze in vitro, two groups can be distinguished in insects, the $\alpha$-esterases which hydrolyze preferably $\alpha$-naphthyl-acetate, and $\beta$-esterases which hydrolyze preferably $\beta$-naphthyl-acetate (Oakeshott et al. 1993). Also as a classificatory criterion, according to the sensibility to different inhibitors of the enzymatic activity and to the amino acid residues in its active site, there are four esterase classes, the acetylesterases (E.C. 3.1.1.6), the arylesterases (E.C. 3.1.1.2), the carboxylesterases (E.C. 3.1.1.1) and the cholinesterases which includes the acetylcholinesterases (E.C. 3.1.1.7) and the pseudocholinesterases (E.C. 3.1.1.8) (Healy et al. 1991).

Little is known about the esterases in T. angustula and T. fiebrigi, known as the jataí stingless bee. Ruvolo-Takasusuki et al. (2006) showed the esterase activity regions in $T$. angustula, and these authors have found two regions, which were characterized as EST-1 ( $\beta$-esterase) and EST-2 ( $\alpha \beta$-esterase).

The objective in the present study is to identify isoenzyme esterase as a biochemical marker which differentiates the two species of jataí stingless bee, T. angustula and T. fiebrigi.

\section{MATERIALS AND METHODS}

\section{Material}

Adult jataí stingless bee workers were collected from two natural nests located within the State University of Maringá (Universidade Estadual de 
Maringá), Paraná (2324'40” S; 51 56 '23” W), one nest was of T. angustula species and the other of T. fiebrigi. After collection, the bees were euthanized and stored in properly labelled and numbered containers, at $-20^{\circ} \mathrm{C}$.

\section{Preparing of the samples and electrophoresis PAGE}

Each bee worker had its head/thorax removed and homogenized individually in propylene tubes $1.5 \mathrm{~mL}$ containing $35 \mu \mathrm{L}$ of $0.1 \% 2$-mercaptoetanol solution plus glycerol at $10 \%$. The samples were centrifuged at $56.000 \mathrm{G}$ for 10 minutes at $4^{\circ} \mathrm{C}$.

Vertical electrophoreses were performed, using PAGE gels at $8 \%$ concentration and stacking gel at $5 \%$ concentration. Tris-Glicine at $0.1 \mathrm{M} \mathrm{pH} 8.3$ was used as buffer. The gels were submitted to electrophoresis at $200 \mathrm{~V}$ for 5 hours.

The gel was incubated for 30 minutes in $50 \mathrm{~mL}$ of sodium phosphate buffer solution (0.1 M pH 6.2), for staining. Then the buffer was discarded and the staining solution was added $-50 \mathrm{~mL}$ of sodium phosphate buffer at $0.1 \mathrm{M} \mathrm{pH}$ 6.2, $0.03 \mathrm{~g}$ of $\alpha$-naphthyl acetate; $0.03 \mathrm{~g}$ of $\beta$-naphthyl acetate, $0.06 \mathrm{~g}$ of Fast Blue RR Salt. The gel was incubated until the bands became visible.

The gels remained in fixation solution (acetic acid at $75 \%$ and glycerol at $10 \%$, dissolved in $1.000 \mathrm{~mL}$ of distilled water) for at least 24 hours. The gels were then soaked in gelatin at $5 \%$ and placed between two sheets of wet cellophane paper, stretched, pressed and kept in room temperature until completely dry (Ceron et al. 1992).

\section{Inhibition tests}

The head/thorax extracts of each worker were used twice in the same PAGE gel, the first trial as the control, and the second as the inhibition test.

For the staining, first, the gel was cut and separated in two parts: control and inhibition. Each part, separately, was incubated for 30 minutes in $50 \mathrm{~mL}$ of sodium phosphate buffer solution ( $0.1 \mathrm{M} \mathrm{pH} \mathrm{6.2).} \mathrm{The} \mathrm{inhibitor} \mathrm{to} \mathrm{be}$ tested was the incubation buffer for the test gel (organophosphate $-60 \mu \mathrm{L}$, parachloromercuriobenzoate $(\rho-C M B)-0.01 \mathrm{~g}$ or eserine sulphate -0.06 g). After the incubation period, the buffer was discarded and the staining solution added as previously described. For the test, the inhibitor was added in the amounts described above. Bands in the control gel were compared with the inhibitor gel, and an inhibition table was produced. 


\section{Thermostability}

The thermostability test for the esterases was done through the pre incubation of the samples for 5 minutes at a temperature that ranged from $52^{\circ} \mathrm{C}$ to $58^{\circ} \mathrm{C}$. After the incubation, $10 \mu \mathrm{L}$ of the supernatant was applied in the PAGE gel and submitted to electrophoresis.

As control, head/thorax extracts of T. angustula and T. fiebrigi which were not submitted to pre incubation were used. After the electrophoresis, the gels were stained for the esterase visualization as described above.

\section{RESULTS AND DISCUSSION}

Many differences were detected in the electrophoretic analysis, regarding the number of observed esterases, migration pattern, affinity to the substrate and thermostability, providing input that the Tetragonisca genus has two species, T. fiebrigi and T. angustula, as suggested by Camargo \& Pedro (2007).

The number of regions with esterase activity varied according to the species; in T. fiebrigi, three esterases were observed, which were called EST-1 (showing a most anodic migration), EST-2 (showing a intermediary migration) and EST-4 (showing a least anodic migration), while in T. angustula, two esterase activity regions were observed: EST-3 (most anodic) and EST-4 (least anodic) (Fig. 1).

Ruvolo-Takasusuki et al. (2006) and Stuchi et al. (2008) classified the T. angustula esterases according to their migration pattern as follows: EST-1 (most anodic) andEST-2 (least anodic). However, due to the results obtained in the present study, it has been suggested that these esterases could be classified as EST-3 (most anodic) and EST-4 (least anodic), and EST-3 is a specific region of $T$. angustula (Fig. 1).

According to the specificity to the substrates $\alpha$-naphthyl-acetate and $\beta$-naphthyl-acetate in T. fiebrigi the EST-1 has been classified as $\beta$-esterase, EST-2 as $\alpha$-esterase and EST- 4 as $\alpha \beta$-esterase (Fig. 1).

The biochemical characteristics described above identified the EST-1 and EST-2 as molecular markers for T. fiebrigi, and EST-3 as molecular marker for T. angustula.

Insect esterases have been divided in four distinct classes based on their sensibility to three groups of inhibitors: organophosphates, eserine sulphate and sulphidril reagents (Healy et al. 1991). In this work, after the electro- 
Table 1. Inhibition pattern for the characterization of esterases using the inhibitors Malathion, p-CMB, and eserine sulfate in Tetragonisca fiebrigi and Tetragonisca angustula. (+) inhibition, (-) no inhibition.

\begin{tabular}{lllll}
\hline \hline Esterase & Malathion & $\rho$-CMB & Eserine sulfate & Classification \\
\hline T. fiebrigi & & & & \\
EST-1 & + & - & + & Cholinesterase (I) \\
EST-2 & + & + & + & Cholinesterase (II) \\
EST-4 & + & + & - & Carboxylesterase \\
T. angustula & & - & & \\
EST-3 & - & - & - & Acetylesterase \\
EST-4 & + & + & - & Carboxylesterase \\
\hline \hline
\end{tabular}

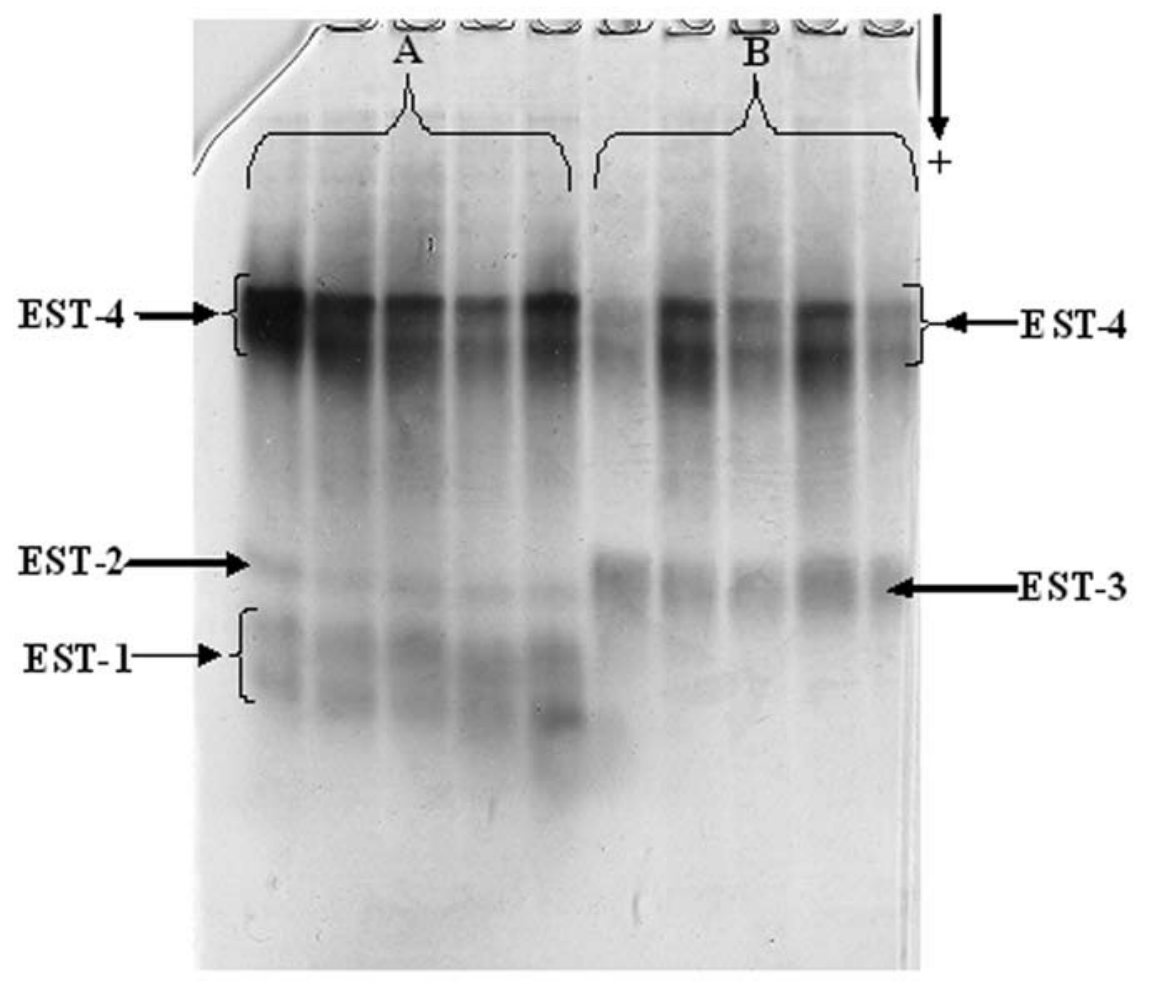

Fig. 1. Esterase isoenzymes profile in the PAGE system from head/thorax extracts of the Tetragonisca fiebrigi (A) and Tetragonisca angustula (B) workers. 
phoresis, head/thorax extracts from the worker bees were submitted to the three groups of inhibitors, the results concerning the inhibition pattern can be observed in Table 1.

Due to their inhibition pattern against the used inhibitors, EST-1 and EST2 in T. fiebrigi can be classified as cholinesterases, EST-1 as a cholinesterase type I, while EST-2 is a cholinesterase type II. The EST- 4 from both species is a carboxylesterase (Table 1). In T. angustula, EST-3 is an acetylesterase.

The analyzed esterase inhibition pattern shows that $T$. fiebrigi presents two cholinesterases and a carboxylesterase and that $T$. angustula presents a carboxylesterase (Table 1). The carboxylesterases and the cholinesterases are common isoenzymes in insects, possibly due to their fundamental role in the process of detoxification of xenobiotic compounds, contributing to a resistance to insecticides. Regarding the organophosphates, these mechanisms involve the increase in the metabolic detoxification by hydrolysis or the kidnapping of these compounds (Hemingway 2000; Lee \& Lees 2001; Cui et al. 2007) or structural changes in the acetylcholinesterase, the primary target for this insecticide class (Hsu et al. 2006).

Therefore, bees from the genus Tetragonisca may be used in future studies as bio-indicators of the presence of pesticides in natural and cultivated areas.

The thermostability tests have shown that there are differences in the esterases inhibition dependingon the temperature in which they are submitted. In T. fiebrigi, when the head/thorax extracts were submitted to a temperature of $52^{\circ} \mathrm{C}$, the EST-4 presented a partial reduction of its activity, while the EST-1 and EST-2 presented total inhibition. Regarding T. angustula, partial inhibition was observed for EST-4, while EST-3 was not inhibited at the same temperature. However, from $54^{\circ} \mathrm{C}$, every esterase lost its activity (Fig. 2 and Table 2).

Concerning the thermostability it is possible to observe that the EST-4 from T. fiebrigi and EST-3 and EST-4 from T. angustula are more thermostable than the EST-1a from Apis mellifera. Ruvolo-Takasusuki et al. (1997) have observed that there was no activity of the EST-1a of $A$. mellifera when extracts from abdomen were previously incubated at $50^{\circ} \mathrm{C}$ or for over 4 minutes, while the T. angustula and T. fiebrigi ones were submitted to $52^{\circ} \mathrm{C}$ for 5 minutes and still remained active (Table 2). 
EST-3 of T. angustula was the most thermostable esterase (Fig. 2), losing its activity at $54^{\circ} \mathrm{C}$. Ruvolo-Takasusuki et al. (1998) observed a high thermostability for $A$. mellifera EST-2, which showed activity after pre-incubation at $60^{\circ} \mathrm{C}$ for 8 minutes.

The esterase biochemical characterization showed that only EST-4 is common in the two species. The EST-1 (T. fiebrigi) and EST-3 (T. angustula) probably have differentiated by mutations along the evolution of both

Table 2. Inhibition patterns of esterases in Tetragonisca fiebrigi and Tetragonisca angustula at $52^{\circ} \mathrm{C}$ and $54^{\circ} \mathrm{C} .(++)$ total inhibition, (+) partial inhibition, (-) no inhibition.

\begin{tabular}{llllll}
\hline \hline Temperature & T. fiebrigi & & \multicolumn{3}{c}{ T. angustula } \\
\hline & EST-1 & EST-2 & EST-4 & EST-3 & EST-4 \\
$52^{\circ} \mathrm{C}$ & ++ & ++ & + & - & + \\
$54^{\circ} \mathrm{C}$ & ++ & ++ & ++ & ++ & ++ \\
\hline \hline
\end{tabular}

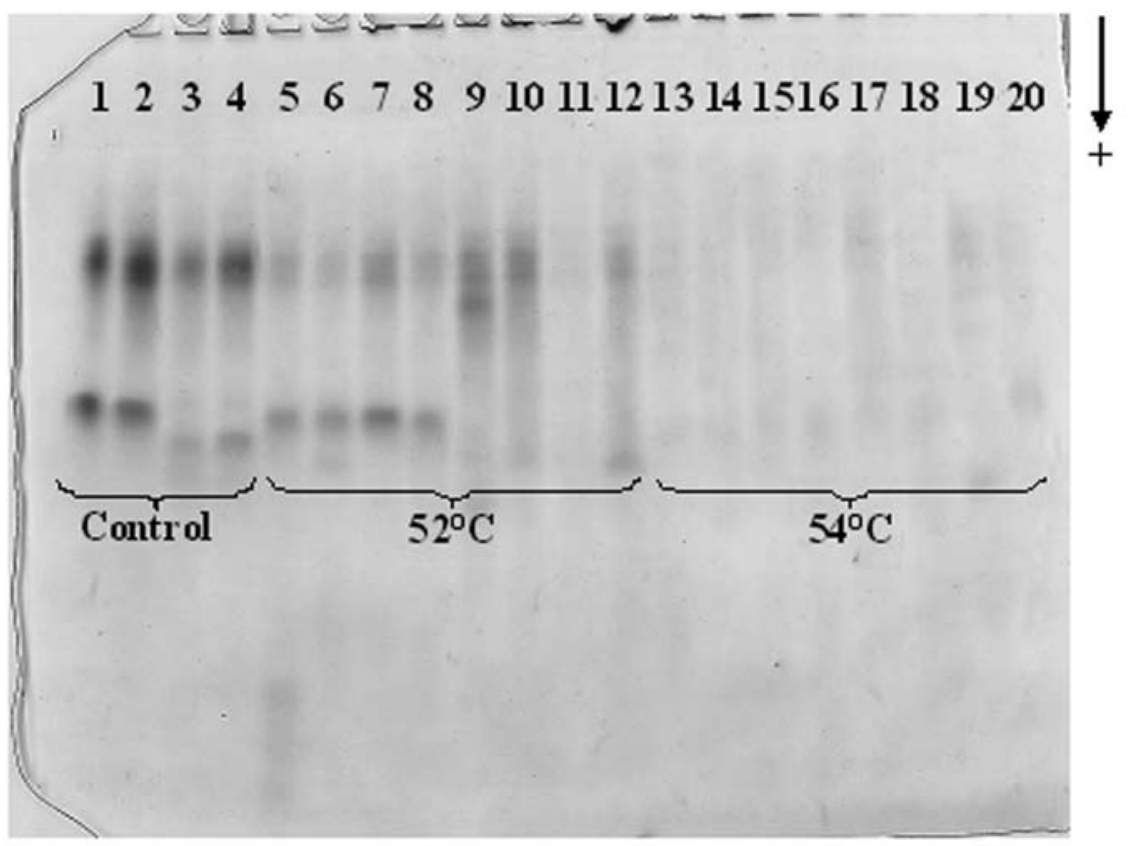

Fig. 2. Thermostability profile of the esterase isoenzymes in the PAGE system from head/thorax extracts of Tetragonisca fiebrigi and Tetragonisca angustula workers. Samples 1-2, 5-8 and 13-16 are head/thorax extracts of Tetragonisca angustula and samples 3-4, 9-12 and 17-20 are head/thorax extracts of Tetragonisca fiebrigi. 
species, and EST-2 (T. fiebrigi) may have been originated by duplication and later mutations.

The use of RAPD markers has shown that T. a. angustula and T. a. fiebrigi may be separated in two groups considered subspecies (Oliveira et al. 2004). On the other hand the use of RAPD by Baitala et al. (2006), in five T. a. angustula and T. a. fiebrigi populations from Junqueirópolis (SP), Maringá (PR) and Cianorte (PR), have not permitted the separation of the two subspecies; only the populations from São Paulo and Paraná states were separated by RAPD markers.

Alves (2006) has applied RAPD for the analysis of three jataí populations in north-eastern Paraná state, Ivatuba, Umuarama and Altônia counties, and in Ivatuba collected only T. a. angustula and in Umuarama and Altônia only T. a. fiebrigi. The results have shown that the two bee species are separated with genetic distance values which justify their taxonomy, as between T. $a$. angustula and T. a. fiebrigi the genetic distance value according to Nei (1978) was 0.23 and between the two T. a. fiebrigi populations was 0.0507 .

Castanheira \& Contel (2005) have performed a morphometric analysis of the wings, mesepisterna staining and hexokinase polymorphism of T. $a$. angustula and T. a. fiebrigibees from various regions within São Paulo, Paraná, Mato Grosso do Sul and Minas Gerais states of Brazil. The mesepisterna coloring and the allele $H K^{88}$ frequency have enabled the authors to suggest that there is clinal distribution or race mixing between the two subspecies. A high correlation between the yellow coloring of the mesepisterna and the allele $H K^{88}$ frequency has been observed.

Diniz-Filho et al. (1998) have performed morphometric analysis of $T$. angustula from central and south-eastern Brazil. The obtained variations could be explained by secondary contact among previously isolated races.

The controversy regarding the two species or subspecies of Tetragonisca seems to be nearly over, because the electrophoretic profile and the esterase biochemical characterization of these stingless bees have shown that they are two distinct species. The obtained results by the esterase biochemical characterization have shown that there are differences in these loci between the two species, which justifies their classification according Camargo \& Pedro (2007). 
The results show that the jataí stingless bees are an important group for speciation studies. The two species have probably originated from one that may have been differentiated due to geographical isolation. Anthropic action and a relatively short period of geographical isolation may have put the two species in touch again which could be causing the hybridization detected in the study performed by Castanheira \& Contel (2005). The observed similarities using the RAPD marker could be due to the use of nonspecific primers and the short time that the two species have been apart. Molecular markers such as PCR-RFLP may contribute to new taxonomic analysis and the systematics of these native stingless bees.

Finally, it may be concluded that the results presented confirm that the jataí stingless bees are actually two species, T. fiebrigi and T. angustula, and that the EST-1, EST-2 and EST-3 are molecular markers which identify them efficiently.

\section{REFERENCES}

Alonso, W.J. 1998. Abelhas sem ferrão: centenas de espécies para polinização, produção de mel, lazer e educação. Artigos técnicos. Animais de criação - Abelhas. 626. [online] http:// www.snagricultura.org.br/artitec_abelhas.htm (acesso em 01 dezembro 2008).

Alonso, W. J. \& C. S. Paim. 2001. As abelhas sem ferrão. [online] http://www.unifap.br/ abelhas (acesso em 01 dezembro 2008).

Alves, D. J. 2006. Uso do marcador molecular RAPD para estudo de polimorfismos em populações de Tetragonisca angustula L. (Apidae: Meliponinae). Dissertação de Mestrado em Genética e Melhoramento. Universidade Estadual de Maringá, Maringá, PR. 45p.

Baitala, T. V., C. A. Mangolin, V. A. A. Toledo \& M. C. C. Ruvolo-Takasusuki. 2006. RAPD polymorphism in Tetragonisca angustula (Hymenoptera; Meliponinae, Trigonini) populations. Sociobiology 48: 861-873.

Camargo, J. M. F. \& S. R. Menezes-Pedro. 1992. Systematics, phylogeny and biogeography of the Meliponinae (Hymenoptera, Apidae): a mini-review. Apidologie 23: 509-522.

Camargo, J. M. F. \& S. R. M. Pedro. 2007. Meliponini Lepeletier, 1836. In: Moure, J. S.; Urban, D.; Melo, G. A. R. (Orgs.). Catalogue of Bees (Hymenoptera, Apoidea) in the Neotropical Region. Curitiba, Sociedade Brasileira de Entomologia, pp. 272-578.

Camargo, J. M. F. \& D. A. Possey. 1990. O conhecimento dos Kayapó sobre as abelhas sociais sem ferrão (Meliponinae, Apidae, Hymenoptera): Notas adicionais. Boletim Museu Paraense Emílio Goeldi, nova série Zoologia 6: 17-42.

Castanheira, E. B. \& E. P. B. Contel. 2005. Geographic variation in Tetragonisca angustula (Hymenoptera, Apidae, Mliponinae). Journal Apicultural Research 44: 101-105.

Ceron, C. R., J. R. Santos \& H. E. M. C. Campos Bicudo. 1992. The use of gelatin to dry cellophane wound slab gels in an embroidering hoop. Brazilian Journal of Genetics 15: 201-203. 
Cui, F., H. Qu,J. Cong, X. L. Liu \& C.L. Qiao. 2007. Do mosquitoes acquire organophosphate resistance by functional changes in carboxylesterases? FASEB Journal 21: 35843591.

Diniz-Filho, J. A. F., R. Balestra, F. M. Rodrigues \& E. D. Araújo. 1998. Geographic variation of Tetragonisca angustula angustula Latreille (Hymenoptera, Meliponinae) in Central and Southeastern Brazil. Naturalia 23: 193-208.

Healy, M. J., M. M. Dumancic \& J. G. Oakeshott. 1991. Biochemical and physiological studies of soluble esterases from Drosophila melanogaster. Biochemical Genetics 29: 365-387.

Hemingway, J. 2000. The molecular basis of two contrasting metabolic mechanisms of insecticide resistance. Insect Biochemical and Molecular Biology 30: 1009-1015.

Hsu,J.C., D.S. Haymer,J. W. Wu \& H.T.Feng.2006. Mutations in the acetycholinesterasegene of Bactrocera dorsalis associated to organophosphorus insecticides. Insect Biochemical and Molecular Biology 36: 396-402.

Iwama, S. \& T. S. Melhem. 1979. The pollen spectrum of the honey of Tetragonisca angustula angustula, Latreille (Apidae, Meliponinae). Apidologie 10: 275-295.

Lee, S. E. \& E. M.Lees. 2001. Biochemical mechanisms of resistance in strains of Oryzaephilus surinamensis (Coleoptera: Silvanidae) resistant to malathion and chlorpyrifos-methyl. Journal of Economic Entomology 94: 706-713.

Macías-Macías, O., J. Chuc, P. Ancona-Xiu, O. Cauich \& J. J. G. Quezada-Euán. 2009. Contribution of native bees and Africanized honey bees (Hymenoptera: Apoidea) to solanaceae crop pollination in tropical México. Journal of Applied Entomology 133: 456-465.

Michener, C.D. 2000. The bees of the world. The John Hopkins University, Baltimore, MD.

Moure, J. S. 1961. A preliminary supra-especific classification of the Old World Meliponine bees (Hymenoptera, Apoidae). Studia Entomologica 4: 181-242.

Moure, J. S., D. Urban \& G. A. R. Melo. 2007. Catalogue of bees (Hymenoptera, Apoidea) in the Neotropical region. Soc. Bras. Entomol. Curitiba, Brasil.

Nei, M. 1978. Estimation of average heterozigosity and genetic distance from a small number of individuals. Genetics 89: 583-590.

Nogueira-Neto, P. 1970. A criação das abelhas indígenas sem ferrão. 2. ed. São Paulo: Chácaras e Quintais.

Nogueira-Neto, P. 1997. Vida e criação de abelhas indígenas sem ferrão. São Paulo: Nogueirapis.

Oakeshott, J. G., E. A. Papenrecht, T.M.Boyce, M.J.Healy \& R.J. Russel. 1993. Evolutionary genetics of Drosophila esterases. Genetics 90: 239-268.

Oliveira, R.C., F. M. F. Nunes, A. P. S. Campos, S. M. Vasconcelos, D. Roubik, L. R. Goulart \& W. E. Kerr. 2004. Genetic divergence in Tetragonisca angustula Latreille, 1811 (Hymenoptera, Meliponinae, Trigonini) based on RAPD markers. Genetic and Molecular Biology 27: 181-186.

Roubik, D. W. 1983. Nest and colony characteristics of stingless bees from Panamá (Hymenoptera: Apidae). Journal of Kansas Entomology Society 56: 327-355. 
Ruiz, J. B. 2006. Análise genética de populações em Tetragonisca angustula na região noroeste do Paraná por meiode isoenzimas. Dissertação de Mestrado em Genética e Melhoramento. Universidade Estadual de Maringá, Maringá, PR. 59p.

Ruvolo-Takasusuki, M.C.C., M.A.DelLama \& A.E.E.Soares. 1997. Genetic characterization of a new Apis mellifera esterase. Apidologie 28: 259-267.

Ruvolo-Takasusuki, M. C. C., M. A. Del Lama \& A. E. E. Soares. 1998. Esterase-2 polymorphism in Apis mellifera. Journal of Apicultural Research 37: 17-22.

Ruvolo-Takasusuki, M. C. C., L. H. O. Viana, T. V. Baitala, K. C. Nicolin \& V. A. A. Toledo. 2006. Characterization of esterases in Tetragonisca angustula and Tetragona clavipes (Hymenoptera; Meliponinae). Brazilian Journal of Morphological Science 23: 431-434.

Stuchi, A. L. P. B., M. C. C. Ruvolo-Takasusuki \& V. A. A. Toledo. 2008. Análise da genética de populações em abelhas jataí (Tetragonisca angustula Latreille) por meio de isoenzimas, Magistra 20: 68-77.

Schwarz, H. F. 1938. The stingless bees (Meliponidae) of British Guiana and some related forms. Bulletin of the American Museum of Natural History 74: 437-508.

Veen, J. W. van \& M. J. Sommeijer. 2000a. Observation of gynes and drones around nuptial flights in the stingless bees Tetragonisca angustula and Melipona beecheii (Hymenoptera, Apidae, Meliponinae). Apidologie 31: 47-54.

Veen, J.W. van \& M. J. Sommeijer. 2000b. Colony reproduction in Tetragonisca angustula (Apidae, Meliponini). Insect Sociology 47: 70-75.

Vit, P., S. Bogdanov, V. Kilchenmann. 1994. Composition of Venezuelan honeys from stingless bees (Apidae: Meliponinae) and Apis mellifera L. Apidologie 25: 278-288.

Walker, C.H. \& M.I.Mackness. 1983. Esterases: problems of identification and classification. Biochemical Pharmacology 32: 3265-3269.

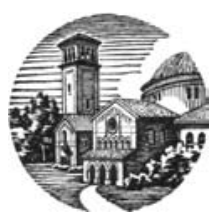

